\title{
PERLINDUNGAN HUKUM TRANSAKSI J UAL BELI KOMPUTER RAKITAN MENURUT UNDANG-UNDANG TENTANG PERLINDUNGAN KONSUMEN (Studi Di Bintan Risky Computer Surabaya)*
}

\author{
Erie Hariyanto \\ J urusan Syari'ah STAIN Pamekasan \\ E-mail: erie.mh@gmail.com
}

\begin{abstract}
In the computer trade is known two terms of the computer type namely Branded computer, which is usually sold in a well packet, assembled by the producer (company) and the second one is assembly computer that nowadays dominates more than $60 \%$ of computer market share in Indonesia in which the trade transaction makes many obstacles which need the solution and law protection for those involved in the trade transaction of assembly computer. By being prevailed the law of number 8 , 1999 about consumer protection, it is wondered whether it has given the law protection for those who are involved especially the consumers. It can be devided into three stages, they are preliminary transaction or the bargain of assembly computer through advertisement, the transaction or agreement of the assembly computer trade and the last is the transaction of sale after service that also concerns with the guarantee. The form of lawsuit solution is commonly done by the familial relathionship between the consumer and the seller. It is the best and effective solution, although the law of the consumer protection also gives the place to complain their cases through the consumer lawsuit affairs.
\end{abstract}

Key words: law protection, trade transaction, assembly computer

\begin{abstract}
Abstrak
Dalam perdagangan komputer dikenal dua istilah mengenai jenis komputer yaitu Komputer Branded dimana biasanya dijual dalam satu unit komputer utuh (well Packet) yang dirakit oleh produsen (pabrik) dan jenis kedua komputer rakitan dimana sekarang menguasai lebih dari $60 \%$ pangsa pasar komputer di Indonesia dimana traksaksi jual belinya menimbulkan banyak hambatan yang mana dituntut pemecahan dan perlindungan hukum bagi para pihak yang terlibat dalam transaksi jual beli komputer rakitan tersebut. Dengan diberlakukannya Undang-undang No.8 Tahun 1999 tentang perlindungan konsumen apakah sudah memberikan perlindungan hukum bagi para pihak utamanya konsumen dimana secara garis besar dapat dibagi dalam tiga tahap yaitu tahap Pra transaksi atau penawaran komputer rakitan melalui iklan, tahap transaksi atau perjanjian jual beli komputer rakitan dan yang terakhir tahap pasca transaksi (sale after service) yang menyangkut juga tentang jaminan garansi. Pada umumnya bentuk penyelesaikan sengketa dilakukan secara kekeluargaan antara pembeli (konsumen) dengan penjual (pihak toko) hal ini paling tepat dan efektif, walaupun Undang-Undang Tentang Perlindungan Konsumen juga memberikan saluran untuk mengadukan kasusnya melalui Badan Penyelesaian Sengketa Konsumen.
\end{abstract}

Kata kunci: perlindungan hukum, transaksi jual beli, komputer rakitan

\section{Pendahuluan}

Dewasa ini tidak ada kegiatan manusia modern yang lepas dari teknologi komputer yang dapat membantu dalam menyelesaikan tugas-tugasnya secara cepat dan efisien. Dalam

Tulisan ini merupakan artikel dari hasil penelitian invidual (tesis) penulis pada Program Pascasarjana Universitas Islam Malang tahun 2006 perkembangannya komputer telah dapat merubah kebiasaan atau gaya hidup yang beralih dari alam wujud atau fisik ke alam elektronik atau non fisik disebut sebagai ruang maya (cyberspace), kita dapat melakukan segala kegiatan melalui internet misalnya memesan barang, memesan tiket pesawat dan sebagainya yang 
lebih dikenal dengan kegiatan perdagangan elektronik (E-Commerce).

Perkembangan komputer tidak lepas pengertian dari komputer yang diberikan oleh para pakar, diantaranya adalah pendapat Robert $\mathrm{H}$. Blissmer yang menekankan pengertian komputer berdasarkan fungsi umum dari komputer. Menurut beliau, dalam bukunya Computer Annual, pengertian komputer yaitu "suatu alat yang mampu melakukan tugas seperti menerima, memproses input tadi sesuai dengan programnya, dan menyimpan perintah-perintah dan hasil dari pengolahan, menyediakan output dalam bentuk informasi". Menurut Donald H. Sanders, pengertian dari komputer adalah "sistem elektronik untuk memanipulasi data yang cepat dan tepat serta dirancang dan diorganisasi supaya otomatis menerima dan menyimpan data input, memprosesnya dan menghasilkan output dibawah pengawasan suatu langkahlangkah instruksi-instruksi program yang tersimpan di memori (storage program)" ${ }^{1}$.

Ada dua istilah dalam perdagangan komputer mengenai jenis komputer yaitu komputer branded (merk terkenal) dan komputer rakitan (komputer lokal) dimana keduanya memiliki perbedaan dalam sistem perdagangannya, perjanjian jual beli dan aspek perlindungan hukumnya, utamanya perlindungan bagi konsumen terhadap komputer yang dibelinya. Komputer branded (merk terkenal) lebih terjamin, khususnya dalam hal spesifikasi hardwarenya karena sebelum dirangkai sebuah komputer harus melalui berbagai macam uji tes, sehingga konsumen membeli produk dalam satu unit komputer yang utuh (well packet) yang sudah terjamin kualitasnya. Pihak produsen komputer branded memberi layanan purna jual yang baik, dengan memberi jaminan garansi antara satu sampai tiga tahun serta petunjuk pemakaian yang sudah disertakan bersama komputer tersebut. Produsen komputer Branded tidak perlu

Erie Hariyanto, "Problematika dan Perlindungan Hukum e-Commerce di Indonesia", Jurnal al-ihkam Vol.4 No.2 Desember 2009, Jurusan Syari'ah STAIN Pamekasan, hlm, 294,; bandingkan dengan Purba, Onno W dan Aang Arid Wahyudi, "Mengenal e-commerce", (J akarta: Elex Media Komputindo, 2000), hlm 12, diragukan misalnya Compaq, vendor memberikan fasilitas ask compaq dalam website-nya. Begitu pula vendor Zyrex membuat technical service center dibeberapa tempat yang dapat digunakan oleh konsumennya. Konsekuensi dari hal itu adalah harga produk dari komputer branded terpaut jauh dari komputer rakitan.

J enis komputer yang kedua dalam dunia perdagangan komputer dikenal dengan komputer rakitan, sering disebut komputer lokal atau generik adalah komputer dimana komponen dan aksesoris dari komputer dirakit oleh pihak penjual sendiri artinya suatu komputer dirakit sesuai dengan komponen yang ada dipasaran saat komputer itu dirakit artinya tidak melalui proses pengujian (burning test) sehingga jaminan kualitas produk itu kurang. Selain itu tidak ada jaminan purna jual karena tidak menutup kemungkinan sebuah toko komputer rakitan secara tidak terduga beralih haluan menjual ponsel atau sudah gulung tikar (tokonya sudah tutup). Hambatan lain yang sering muncul dalam perdagangan komputer rakitan kadangkala pihak penjual mengelabuhi pembeli dengan memanfaatkan ketidaktahuan pembeli (konsumen) berkenaan dengan komputer rakitan yang akan dibeli seperti memasangkan komponen komputer tidak sesuai dengan yang diperjanjikan atau penjual memasangkan barang bekas dalam komputer rakitan tanpa memberitahukan kepada konsumen untuk sekedar memperoleh keuntungan.

Ada kalanya konsumen tidak beritikad baik atau kurang terampil menggunakan komputernya sehingga mengakibatkan kerusakan yang semestinya tidak terjadi, sehingga sulit mengetahui apakah memang kerusakan di timbulkan karena kesalahan pemakaian atau karena dari komponen komputer itu sendiri sehingga dapat menimbulkan konflik antara pedagang dan pembeli (konsumen). Walaupun kualitas dan jaminan purna jualnya tidak sebaik dengan komputer branded (merk terkenal). Namun kenyataanya komputer jenis rakitan yang menguasai pangsa pasar lebih dari $60 \%$ kom- 
puter di Indonesia. ${ }^{2}$ Hal ini mungkin dipengaruhi oleh kemampuan ekonomi dari masyarakat Indonesia yang masih rendah namun dituntut kebutuhan untuk mempunyai sebuah komputer untuk menunjang aktifitasnya. Sehingga komputer rakitan menjadi pilihan utamanya.

Besarnya jumlah penjualan komputer rakitan dan besarnya potensi untuk terjadi kasuskasus yang merugikan utamanya konsumen maka diperlukan adanya perlindungan hukum bagi konsumen, sesuai dengan pasal 27 Ayat (1) Undang-undang Dasar 1945 menyatakan, "Bahwa segala warga negara Indonesia bersamaan kedudukannya dalam hukum dan pemerintahan itu dengan tidak ada kecualinya". Pasal tersebut pada dasarnya memberikan landasan konstitusional bagi perlindungan konsumen di Indonesia karena dalam ketentuan itu secara jelas dinyatakan bahwa kedudukan hukum semua warga negara adalah sama (equality before the law). Begitu juga kedudukan hukum konsumen, tidak boleh lebih rendah dari pada produsen atau pemasar produk produsen. Para pihak memiliki hak-hak yang seimbang satu sama lainnya yang dijamin oleh Undang-undang.

Penerapan peraturan hukum perlindungan konsumen seringkali merefleksikan ketidakseimbangan kekuatan antara pelaku usaha dan konsumen dianggap pihak lebih lemah dalam transaksi sehingga aturan-aturan serta regulasi khusus dikeluarkan untuk melindungi kepentingan konsumen. ${ }^{3}$ Dilihat dari kaca mata produsen, konsumen adalah obyek dari suatu strategi pemasaran atau target dari pasar produsen atau sering disebut sebagai pangsa pasar sehingga banyak usaha yang dilakukan oleh para produsen atau penjual mempromosikan barang yang di jualnya dengan berbagai macam cara walaupun kadangkala menyesatkan pembeli (konsumen). Sebaliknya kalau dilihat dari sudut

2 "Serba Super di PC Branded", Majalah Komputer Aktif, Edisi 30 J anuari No. 20, 2005,

3 Abdul Hakim Barkatullah, "Bentuk Perlindungan Hukum Bagi Konsumen dalam Penyelesaian Sengketa Transaksi Elektronik Internasional menurut UU No. 11 Tahun 2008", Jurnal Hukum Bisnis, Vol. 29 No. 1, Tahun 2010, hlm 58,; Bandingkan dengan Yun Zhao, "Dispute Resolution in Elektronic Commerce" (Leiden/Boston: Martinus Nijhoff Publisher, 2005), hlm 118, pandang yuridis maka konsumen merupakan subyek hukum yang mempunyai hak dan kewajiban hukum, dalam hal ini pemerintah memperhatikan dengan lahirnya Undang-undang No. 8 tahun 1999 tentang perlindungan konsumen yang aspiratif melindungi kepentingan dan hak dari konsumen yang cendrung dikesampingkan oleh pelaku usaha atau penjual, disamping juga pelaku usaha dilindungi dari pembeli (konsumen) yang tidak mempunyai itikad baik dalam bertransaksi.

\section{Permasalahan}

Berdasarkan latar belakang tersebut diatas, penulis tertarik untuk membahas dua hal. Pertama mengenai perlindungan hukum dalam transaksi jual beli komputer rakitan berdasarkan Undang-undang No. 8 tahun 1999 Tentang Perlindungan Konsumen; dan kedua, faktor penghambat dan upaya penyelesaiannya dalam transaksi jual beli komputer rakitan.

\section{Metode Penelitian}

Penelitian ini menggunakan pendekatan kualitatif sebagai sebuah tradisi dalam ilmu pengetahuan sosial yang secara fundamental bergantung kepada pengamatan manusia dalam kawasannya sendiri dan berhubungan dengan orang-orang tersebut dalam bahasanya dan peristilahannya. Pendekatan kualitatif dalam penelitian ini diarahkan pada pendekatan sosiologis yaitu langsung mengamati law in action, dalam hal ini penulis menganalisa per-undangundangan antara lain: Kitab Undang-undang Hukum Perdata buku III Tentang Perikatan dan Undang-undang No. 8 Tahun 1999 Tentang Perlindungan Konsumen. Dari hasil penelitian nantinya diharapkan dapat memberikan model perlindungan hukum bagi para pihak dalam kaitan dengan transaksi jual beli komputer rakitan.

Penggunaan data primer yang dalam penelitian ini berhubungan dengan perlindungan hukum terhadap para pihak dalam transaksi jual beli komputer rakitan, yang didapat undangundang dan dari hasil wawancara secara langsung. Dengan responden sebagai berikut: seorang Direktur Utama Bintan Risky Computer Surabaya, seorang Bagian Pemasaran Bintan 
Risky Computer Surabaya, delapan orang Pembeli komputer di Bintan Risky Computer Surabaya, seorang Pengurus di Badan Penyelesaian Sengketa Konsumen (BPSK) Surabaya, seorang Pengurus di Yayasan Lembaga Konsumen Surabaya (YLKS), dan seorang Pengurus di Assosiasi Pedagang Komputer (APKOM) J awa Timur. Data sekunder berupa data yang diperoleh penulis dengan mempelajari dan menganalisa data tertulis yang terdapat dalam peraturan perundang-undangan, buku-buku, surat kabar yang berhubungan dengan masalah yang diteliti.

Analisis data melewati suatu proses yang dimulai saat pengumpulan data dilakukan secara intensif dan hendaknya segera ditafsirkan dan diorganisasikan ke dalam suatu kategori agar untuk membuat uraian dasar mengenai data itu baik data hasil wawancara, observasi dan dokumentasi. Analisis data tersebut dapat dilakukan pada saat pengumpulan data secara tersendiri dan pengumpulan data secara keseluruhan. Untuk menganalisis perlindungan dan hambatan dalam transaksi jual beli komputer rakitan menurut Undang-Undang No 8 Tahun 1999 Tentang Perlindungan Konsu-men

\section{Pembahasan \\ Perlindungan Hukum dan Penyelesaian Seng- keta Konsumen}

Setiap konsumen yang dirugikan dapat menggugat pelaku usaha melalui lembaga yang bertugas menyelesaikan sengketa antara konsumen dan pelaku usaha atau melalui peradilan yang berada di lingkungan peradilan umum. Penyelesaian sengketa konsumen dapat ditempuh melalui pengadilan atau di luar pengadilan berdasarkan pilihan sukarela para pihak yang bersengketa (Pasal 45 ayat (1) dan ayat (2)). Budaya hukum masyarakat termasuk faktor yang mempengaruhi arti penting penyelesaian sengketa di luar Pengadilan ${ }^{4}$

\footnotetext{
Kurniawan, "Permasalahan dan Kendala Penyelesaian Sengketa Konsumen melalui Badan Penyelesaian Sengketa Konsumen (BPSK)", J urnal Dinamika Hukum, Vol 12 No. 1, Tahun 2012, hlm.164,; Bandingkan dengan Syahrizal Abbas, "Mediasi Problem Solving Hukum Syariah, Adat dan Nasional", J urnal Hukum dan Syariah Vol. 1 No. 1, 2010. hlm1,
}

Penyelesaian sengketa konsumen tidak menutup kemungkinan penyelesaian damai oleh para pihak yang bersengketa. Pada setiap tahap diusahakan untuk menggunakan penyelesaian damai oleh kedua belah pihak yang bersengketa. Penyelesaian secara damai adalah penyelesaian yang dilakukan oleh kedua belah pihak yang bersengketa (pelaku usaha dan konsumen) tanpa melalui pengadilan atau badan penyelesaian sengketa konsumen dan tidak bertentangan dengan undang-undang ini (Penjelasan Pasal 45 ayat (1) dan ayat (2) UU No. 8 Tahun 1999).

Berdasar Pasal 49 UU No. 8 Tahun 1999 ada Badan Penyelesaian Konsumen (BPSK) di daerah kabupaten atau kotamadya untuk penyelesaian sengketa konsumen di luar pengadilan. Dengan merujuk pada Pasal 49 ayat (1) dan Pasal 54 ayat (1) UU No. 8 Tahun 1999 jo Pasal 2 SK Menperindag Nomor 350/MPP/ Kep/12/ 2001 fungsi utama BPSK yaitu: sebagai instrumen hukum penyelesaian konsmen di luar pengadilan sedangkan tugas BPSK pada Pasal 52 butir e. butir $\mathrm{f}$, butir $\mathrm{g}$, butir $\mathrm{h}$, butir $\mathrm{h}$, butir I, butir $\mathrm{j}$, butir $k$, butir I dan buitr m UUPK sebenarnya telah terserap dalam fungsi utama BPSK tersebut. Tugas BPSK memberikan konsultasi perlindungan konsumen (Pasal 52 butir $b$ UUPK) dapat dipandang sebagai upaya sosialisasi Undang-Undang Perlindungan Konsumen, baik terhadap konsumen maupun pelaku usaha. ${ }^{5} \mathrm{Da}$ lam hal konsultasi diberikan, jika permohonan sengketa konsumen (PSK) sudah terdaftar di Sekretariat BPSK, maka konsultasi yang diberikan tentu dalam rangka penyelesaian sengketa konsumen, baik dengan cara konsiliasi, mediasi maupun arbitrase.

BPSK memiliki tugas melakukan pengawasan terhadap pencantuman klausula baku (Pasal 52 butir c UUPK tidaklah selalu terkait dengan adanya sengketa konsumen. Dalam hal ini, BPSK diharapkan bersikap proaktif menegakkan norma-norma pencantuman klausula baku yang diamanatkan Pasal 18 UUPK, baik dengan cara-cara persuasive maupun represif un-

\footnotetext{
5 Yusuf Shofie, "Penyelesaian Sengketan Konsumen Menurut UUPK", Citra Aditya Bakti, 2003, hlm. 21,
} 
tuk menguji kepatuhan pelaku usaha terhadap norma-norma tersebut. Adanya bentuk kontrak baku tujuannya untuk menstabilkan hubungan eksternal pasar dengan pelanggan ${ }^{6}$

Penyelesaian sengketa konsumen dilakukan dengan 3 (tiga) cara. Pertama, cara konsiliasi ditempuh atas inisiatif salah satu pihak atau para pihak, sedangkan Majelis BPSK bersikap pasif, Majelis BPSK bertugas sebagai pemerantara antara para pihak yang bersengketa. Kedua mediasi, ditempuh atas inisiatif salah satu pihak atau para pihak. Bedanya dengan yang pertama, pada mediasi Majelis BPSK bersikap aktif sebagai pemerantara dan penasehat. Ketiga arbritase, para pihak menyerahkan sepenuhnya kepada Majelis BPSK untuk memutuskan dan menyelesaikan sengketa konsumen yang terjadi. ${ }^{7}$

Arbitrase merupakan suatu metode penyelesaian sengketa dalam masalah-masalah perdata (civil matters) yang dapat disetujui oleh kedua belah pihak, yang dapat mengikat (binding) dan dapat dilaksanakan/ ditegakkan. Para pihak diwajibkan untuk pergi ke arbitrase atas suatu maslah tertentu sebagai bagian dari suatu perjanjian tentang prosedur penyelesaian sengketa (dispute resolution procedures) yang telah disepakati para pihak terdahulu. ${ }^{8}$ Sebelum para pihak terlibat dalam proses, hasil keputusan arbitrase (the status of the outcome of arbitration) harus disetujui para pihak tersebut. $^{9}$

Ketiga cara penyelesaian sengketa tersebut dilakukan atas dasar pilihan dan persetu-

6 R.M. Panggabean "Keabsahan Perjanjian dengan Klausul Baku", J urnal Hukum, No. 4 Vol. 17, Oktober 2012, hlm. 651,

Yusuf Shofie, "Sengketan Konsumen Menurut UUPK" hlm.22-25 baca juga Kurniawan dan Abdul Wahab, "Tinjauan Yuridis Terhadap Prosedur Penyelesaian Sengketa Konsumen Melalui BPSK di Indonesia" J urnal Hukum Jatiswara, Fakultas Hukum Universitas Mataram, Vol 23, No.2, Juli 2008, hlm. 54,

8 Shahrullah "Modern Arbitration Legislation: A Comparosion Between Australia and Indonesia Law", Mimbar Hukum, Vol 24 No. 2, J uni 2012, hlm. 200,

9 Suyud Margono, "Perlembagaan Alternatif Dispute Resolution (ADR) : dalam Prospek dan Pelaksanaannya di ndonesia",(Bandung : PT Citra Aditya Bakti, 2001), hlm.22,; Baca Juga Adi Sulistiyono "Musyawarah Untuk Penyelesaian Sengketa Win-Win solution dalam Perspektif Hukum", J urnal Hukum Bisnis, Vol. 25 No. 1, Tahun 2006, hlm. 72, juan para pihak dan bukan proses penyelesaian sengketa secara berjenjang. Instrumen hukum lain dapat ditempuh konsumen tanpa terlebih dahulu melalui instrumen hukum BPSK, ke depan ketiga cara penyelesaian sengketa tersebut, dapat berdaya guna (efisien) dan berhasil guna (efektif). Penyelesaian sengketa melalui BPSK yang tugas dan wewenangnya antara lain meliputi pelaksanaan penanganan dan penyelesaian sengketa konsumen melalui mediasi, arbritase atau konsiliasi, yang selain media penyelesaian sengketa juga dapat menjatuhkan sanksi admnistratif bagi pelaku usaha yang melanggar larangan tertentu yang dikenakan bagi pelaku usaha. ${ }^{10}$

Kecenderungan budaya di Indonesia untuk berkrompomi bila timbul perselisihan pribadi tetap kuat dan sama sekali tidak terbatas pada orang-orang desa saja. Membawa perselisihan ke pihak luar berarti menarik perhatian pihak lain. pengadilan memiliki keterbatasan untuk mengetahui semua hubungan yang dipertaruhkan dalam perselisihan lokal, dan pengadilan mungkin menerapkan patokan-patokan yang tidak dikenal dalam adat kebiasaan. Pengaruh politik dari luar dapat memperlemah kemampuan masyarakat untuk mengatasi perselisihan mereka. ${ }^{11}$

Menurut Eman Rajagukguk, budaya hukum masyarakat termasuk faktor yang mempengaruhi arti penting penyelesaian sengketa bisnis diluar pengadilan. Budaya tradisional yang menekankan kepada komunitas, kekerabatan, harmoni, primus inter pares telah mendorong penyelesaian sengketa diluar pengadilan yang formal. Demikian budaya yang menekannkan kepada efisiensi dan efektifitas sama kuatnya mendorong penyelesaian sengketa bisnis tapa melalui pengadilan. ${ }^{12}$

10 Abdul Hakim Barkatullah, "Urgensi Perlindungan Konsumen Dalam transaksi di E-Commerce", Jurnal Hukum, Fakultas Hukum Universitas Islam Indonesia, Vol. 3 No. 3 2007, hlm 260,

11 Yusuf Shofie op.cit, hlm. 22

12 Erman Rajagukguk, "Budaya Hukum dan Penyelesaian Sengketa di Luar Pengadilan:. J urnal Magister Hukum, PPs-UII, Yogyakarta, Vol. 2 N0.4, Oktober 2000, hlm.7,; lihat juga Daniel S. Lev. "Lembaga Peradilan dan Budaya Hukum" dalam Daniel S.Lev Hukum dan Politik Indonesia, Cet I, LP3ES, 1990. hlm. 164-166, 
Konsiliasi yang lazim dilakukan di seluruh Indonesia merupakan sifat budaya hukum Indonesia. di Indonesia sesudah merdeka, konsiliasi dan arbitrase sangat lazim di lingkungan pedagang. Pengadilan pemerintah sering dihindari dengan berbagai alasan, yaitu efisiensi, kemanfaatan dan kepercayaan; pelarian ke prosedur tersembunyi yang tidak resmi dalam perekonomian; dan prosedur peradilan menjerakan para pengusaha, di antaranya prosesnya berliku-liku, ketidakcakapan hakim, dan biaya tidak resmi pengadilan.

Konsiliasi (penyelesaian perselisihan secara kekeluargaan) dan kompromi (penyelesaian perselisihan melalui jalan tengah) cenderung lebih ditekankan pada satuan masyarakat yang kecil-kecil yang di dalamnya hubungan tatap muka lebih menonojol. Sebaliknya, hubungan yang tidak akrab menjadikan keputusan pihak ketiga dengan status resmi lebih tetap. Seorang konsiliator semestinya bersikap atau berbuat: meredakan gejolak amarah dan membawa pihak-pihak untuk terus mengadakan perundingan; memperkecil makna perselisihan dan memperbesar arti hubungan-hubungan pribadi, serta menekankan arti kepentingan bersama; dan mengupayakan kesepakatan para pihak bahwa tidak ada satu pihakpun yang benar dan menang, walaupun secara pribadi mungkin dianggap ada, kedua-keduanya salah karena bertengkar dan telah kembali rukun satu sama lain. Untuk itu perlu diselenggarakan upacara untuk mengukuhkan penyelesaian damainya dan membersihkan suasana yang keruh. ${ }^{13}$

\section{Penerapan Perlindungan Hukum menurut UU No. 8 Tahun 1999}

Predikat konsumen diperoleh sebagai konsekuensi mengkonsumsi barang dan atau jasa melalui suatu transaksi konsumen, perlu diketahui bahwa transaksi konsumen adalah transaksi yang dilakukan oleh konsumen antara dengan pembeli dimana barang tersebut dibeli dengan tujuan untuk dikonsumsi sendiri dan tidak tujuan untuk dijual kembali sehingga terjadi suatu peralihan barang atau jasa, termasuk

13 Ibid., hlm. 159-160, di dalamnya peralihan kenikmatan dalam menggunakannya dari penjual (pelaku usaha) ke pembeli (konsumen). ${ }^{14}$

Selain transaksi konsumen, dikenal juga transaksi komersial, yang biasanya dilakukan oleh produsen sebagai principal dengan pedagang perantara. Pihak yang disebut terakhir ini yang menjembatani antara produsen dan konsumen akhir (ultimate consumer). Itulah sebabnya, para pedagang perantara disebut juga dengan konsumen antara (intermediate consumer) dimana UU No. 8 Tahun 1999 tidak mengkategorikan "konsumen antara" ini sebagai konsumen yang dilindungi oleh Undang-undang.

Konsumen antara (intermediate consumer) dapat berupa distributor atau agen. Kedua istilah ini memiliki sejumlah perbedaan. Distributor bertindak atas namanya, sementara agen melakukan transaksi atas nama principalnya. Dengan demikian, dalam pelunasan harga barang atau jasa, pembeli dapat saja tidak membayar melalui perantaraan agen tapi langsung kepada pihak principal. Hal ini tidak terjadi pada distributor karena produk yang diperjual belikan menjadi miliknya. Karakteristik yang berbeda ini tentu mempengaruhi konstitusi hukum dalam transaksi konsumen diantara para pihak terkait.

Sistem perdagangan komputer rakitan yang banyak terjadi adalah hubungan dengan sistem distributor artinya penjual (pihak toko) dan dealer utama (master dealer) tidak ada hubungan secara keagenan, sehingga barang yang dipunyainya adalah milik pedagang itu sendiri, dan konsumen hanya mempunyai hubungan jual beli dengan pihak penjual, artinya segala keluhan konsumen akan mendapat tanggapan dan pelayanan secara langsung dari penjual komputer rakitan bersangkutan ${ }^{15}$

Transaksi konsumen merupakan suatu perikatan, yang terutama bersangkut paut dengan perikatan keperdataan. Dalam kacamata hukum

\footnotetext{
14 Wiwik Pratiwi, "Keseimbangan Hak dan Kewajiban Antara Produsen dan Konsumen", J urnal IImiah Inkoma, Vol. 18 No. 1, Februari 2007. HIm 15,

15 Wawacara dengan Direktur BRC Surabaya tanggal 18 Desember 2005,
} 
perdata, perikatan transaksi konsumen itu tidak serta merta terjadi begitu saja, ada suatu kegiatan yang mendahuluinya. Perikatan konsumen merupakan pelaksanaan dari perikatan sebelumnya yang dapat disebut pra transaksi konsumen. Setelah transaksi konsumen dilaksanakan, masih ada perikatan lain yang harus dipenuhi oleh kedua belah pihak, yang dapat disebut pasca transaksi konsumen. Begitu pula yang terjadi dalam praktek perdagangan komputer rakitan suatu perjanjian tidak terjadi serta merta dan berakhir dengan sendirinya, namun melalui beberapa tahap yang mana tahap yang satu mempunyai keterkaitan dengan tahap yang lain yang dapat dijabarkan menjadi tiga tahap yaitu tahap pra transaksi komputer rakitan meIalui iklan, tahap transaksi atau perjanjian jual beli komputer rakitan dan yang terakhir tahap pasca transaksi komputer rakitan (after sales service).

\section{Tahap Pra Transaksi atau Penawaran Kompu- ter Rakitan Melalui Iklan}

Tahap pra transaksi konsumen biasanya ditandai oleh penawaran dari penjual kepada calon pembelinya, Iklan sampai saat ini masih bisa dikategorikan sebagai sarana bisnis dari para pemasar yang dipersepsikan masih ampuh untuk meningkatkan pemasaran sebuah produk. ${ }^{16}$ Dalam perdagangan komputer rakitan penawaran lazimnya dilakukan melalui media massa atau bentuk brosur yang ditempel didepan toko yang dikemas secara menarik dengan penawaran harga yang murah sehingga pembeli (konsumen) tertarik dengan itu. Kemasan penawaran demikian disebut dengan iklan. Berkenaan dengan iklan ini, UU No. 8 Tahun 1999 memberikan perlindungan hukum sebagai mana dijelaskan dalam Pasal 10 sampai 17.

Berdasarkan Pasal 10, Pelaku usaha dalam penawaran barang dan/atau jasa yang di tujukan untuk di perdagangkan di larang menawarkan, mempromosikan, mengiklankan atau membuat pernyataan yang tidak benar menge-

\footnotetext{
16 Fransisca Mulyono, "Informasi Produk Dalam Iklan dan Perlindungan Konsumen di Indonesia", Jurnal Bina Ekonomi, Universitas Katholik Parahyangan Bandung, Vol. 14 No. 2, Agustus 2010. hlm. 36,
}

nai: harga atau tarif suatu barang dan/atau jasa; kegunaan suatu barang dan/atau jasa; kondisi, tanggungan, jaminan, hak atau ganti rugi atas suatu barang dan/ atau jasa; tawaran atau potongan harga atau hadiah menarik yang di tawarkan, bahaya penggunaan barang dan/atau jasa.

Pelaku usaha dalam penjualan yang dilakukan melalui cara obral atau lelang, dilarang mengelabui/menyesatkan konsumen dengan: menyatakan barang dan/atau jasa tersebut seolah-olah telah memenuhi standar mutu tertentu; menyatakan barang dan/atau jasa tersebut seolah-olah tidak mengandung cacat tersembunyi; tidak berniat untuk menjual barang yang ditawarkan melainkan dengan maksud untuk menjual barang lain; tidak menyediakan barang dalam jumlah tertentu dan/ atau jumlah yang cukup dengan maksud menjual jasa yang lain; tidak menyediakan jasa dalam kapasitas tertentu atau dalam jumlah cukup dengan maksud menjual jasa yang lain; dan menaikkan harga atau tarif dan/atau jasa sebelum melakukan obral. ${ }^{17}$

Pelaku usaha dilarang menawarkan mempromosikan atau mengiklankan suatu barang dan/atau jasa dengan harga atau tarif khusus dalam waktu dan jumlah tertentu, jika pelaku usaha tersebut tidak bermaksud untuk melaksanakannya sesuai dengan waktu dan jumlah yang ditawarkan, dipromosikan, atau diiklankan. Berkaitan dengan praktek pra transaksi ini yang banyak terjadi adalah adanya pencantuman klausula bahwa harga dan spesifikasi barang dapat berubah sewaktu-waktu sehingga kadang kondisi yang diiklankan berbeda dengan barang yang dijual pada waktu itu atau barang yang ditawarkan dalam iklan ternyata tidak ada, sehingga menawarkan barang yang lain. Dengan alasan fluktuasi nilai tukar mata uang dollar, seorang pedagang menaikkan harga komputer rakitan yang di jualnya.

Penjual komputer rakitan juga mengakali pembeli meski tidak bisa dikatakan menipu de-

\footnotetext{
17 Irna Nurhayati, "Efektifitas Pegawasan Badan Pegawasan Obat dan Makanan Terhadap Peredaran Produk Pangan Olahan Impor dalam mewujudkan Perlindungan Konsumen", Jurnal Mimbar Hukum, Vol. 21 No, 2 J uni 2009, hlm 216
} 
ngan menuliskan sebanyak mungkin komponen pelengkap komputer rakitan pada brosurnya. Sebagai contoh pada brosur akan dijumpai komponen-komponen dengan tulisan "on board" dalam tanda kurung di belakangnya. Padahal komponen on board berarti komponen yang menjadi satu dengan motherboard atau menjadi bagian motherboard. Penjabaran bagianbagian motherboard pada brosur itu akan mengesankan bahwa komputer yang dijual dilengkapi dengan lebih banyak komponen. Bagi pembeli (konsumen) yang tidak tahu akan menyangka komponen-komponen itu merupakan bagian sendiri di luar motherboard, padahal tentu saja komponen yang menjadi satu dengan motherboard itu tidak bisa diupgrade kecuali pengguna mengganti motherboardnya. ${ }^{18}$

\section{Tahap Transaksi J ual Beli Komputer Rakitan}

Seperti dalam perjanjian pada umumnya unsur pokok dari perjanjian jual beli adalah barang dan harga. Sesuai dengan asas "konsensualisme" perjanjian jual beli lahir pada detik tercapainya sepakat mengenai barang dan harga. tahap ini merupakan tahap yang paling penting dari transaksi komputer rakitan yang mana suatu perjanjian jual beli komputer rakitan terjadi pada waktu penjual menulis spesifikasi komponen yang akan dirakit dengan menyebutkan harga, dan pembeli menyatakan setuju dengan harga dan spesifikasi dari komputer rakitan. Namun walaupun komputer rakitan dan harga sudah disetujui, jual beli komputer rakitan baru terjadi setelah pembeli (konsumen) mencoba dan puas akan komputer yang dibelinya tersebut.

Untuk terlaksananya perjanjian jual beli, diawali dengan adanya pembeli (konsumen) yang datang ke toko komputer, kemudian terjadi penawaran yang dilakukan oleh pihak toko dengan memberikan daftar harga komputer rakitan yang dipunyainya. Pada tahap ini pembeli dapat ikut serta dalam menentukan pemilihan komponen dari komputer rakitan sehingga da-

18 Wawacara dengan seorang pembeli di BRC Surabaya tgl 18 Desember 2005, pat disesuikan dengan kemampuan keuangannya dari pembeli.

Bukti telah terjadinya jual beli komputer rakitan adalah kuitansi pembelian yang dikeluarkan oleh pihak penjual (toko) sebagai bukti bahwa konsumen membeli komputer ditokonya dan dianggap sebagai bentuk perjanjian dalam transaksi jual beli komputer rakitan. Dalam kenyataan dilapangan kuitansi itu sendiri tidak menulis spesifikasi dari komponen-komponen dalam satu unit komputer tersebut secara detail sehingga kemungkinan penjual wanprestasi sangat besar. ${ }^{19}$

Setiap produk apapun, yang ditawarkan kepada konsumen, haruslah disertai dengan informasi yang benar atas produk tersebut. Informasi ini sangat penting dan diperlukan agar konsumen tidak sampai mempunyai gambaran yang keliru atas produk itu. Demikian pula dengan penjual wajib untuk memberikan informasi keadaan barang yang dijual dengan benar dan jelas, tidak boleh melebih-lebihkan dan tidak boleh mengurangi informasi, artinya pihak penjual tidak hanya menginformasikan keebihan atau kelemahan-kelemahan produknya. Hal ini wajib dilakukan penjual, agar di kemudian hari konsumen tidak menderita kerugian dari dibelinya komputer rakitan ter-sebut.

Klausula perjanjian dalam transaksi jual beli komputer rakitan meletakkan pembeli (konsumen) pada posisi yang lemah, baik dalam masalah pemilihan komponen ataupun masalah jaminan garansi di mana banyak ditemukan perjanjian yang tidak sesuai dengan UU No. 8 Tahun 1999, yaitu: pertama, barang yang termasuk garansi adalah barang yang rusak karena kesalahan produksi, bukan barang yang rusak disebabkan oleh kesalahan manusia (human error) seperti: jatuh, terbakar, akibat perubahan arus listrik, konsleting, terkena siraman air atau zat kimia lain yang merusak; kedua, untuk satu unit komputer baru, produsen (toko komputer) mengeluarkan garansi service selama 6 bulan (tidak termasuk software), sparepart ba-

19 Paripurna P. Sugarda, "Kontrak Standart: Prinsip Kehati-hatian Bank dan Perlindungan Debitur", J urnal Mimbar Hukum, Vol. 20 No. 2, J uni 2008, Fakultas Hukum UGM Yogyakarta, hlm. 198, 
ru 3 bulan (kecuali monitor, printer, scaner garansi service 6 bulan), jasa reparasi satu bulan (tidak termasuk sparepart), sedangkan barang bekas tidak bergaransi; ketiga, penggantian barang (komponen komputer) yang masih dalam status garansi hanya diberikan untuk barang baru yang rusak dalam jangka waktu paling lama satu minggu; keempat, masalah ketersediaan barang, lamanya reparasi akan berusaha mereparasi sendiri barang tersebut atas perjanjian pelanggan (untuk ini tidak dikenai biaya reparasi), dan jika tidak bisa mereparasi sendiri maka akan berusaha mereparasikan barang tersebut kepada pihak ketiga (untuk ini dikenakan biaya reparasi sesuai dengan tarip jasa reparasi pihak ketiga); dan kelima, garansi tidak berlaku apabila: telah berubah kepemilikannya, telah direparasi kepada pihak ketiga, label garansi rusak, barang tersebut tidak dipergunakan dengan semestinya. ${ }^{20}$

Perjanjian diatas merupakan perjanjian yang umum dipakai oleh pihak penjual komputer rakitan khususnya Bintan Risky Computer Surabaya dengan pembeli yang biasanya dilakukan secara lisan kepada pembeli (konsumen) ${ }^{21}$ Dalam praktek transaksi jual beli komputer rakitan dimana masih ada klausula pengalihan tanggung jawab dalam hal terjadi risiko yang jelas sangat merugikan konsumen. Dalam kaitannya dengan pelaksanaan perjanjian jual beli komputer rakitan ini masing-masing pihak harus menjalankan semua hak dan kewajibannya sebagaimana disebutkan dalam bab terdahulu tentang hak dan kewajiban yang harus dilakukan konsumen dan pelaku usaha dalam hubungannya dengan perjanjian jual beli komputer rakitan.

\section{Tahap Pasca Transaksi Komputer Rakitan (After Sales Service)}

Tahap ketiga dari proses transaksi konsumen ini adalah perikatan setelah peralihan barang atau jasa yang pokok dilakukan. Sering terjadi, untuk pembelian barang-barang terten-

20 Wawancara dengan Bagian Pemasaran BRC Surabaya, 12 Desember 2005,

21 Wawancara dengan Direktur BRC Surabaya tgl 12 Desember 2005, tu produsen atau penyalur produk (penjual) memberikan garansi dalam jangka waktu terbatas, misalnya satu tahun. Selama jangka waktu itu, setiap keluhan konsumen atas barang tersebut, sepanjang bukan disebabkan kesalahan pemakaian, dapat diajukan kepada produsen atau penyalur produk (penjual). Ini biasanya disebut layanan purna jual, Dimana peranan perlindungan hukum bagi konsumen memegang kendali yang sangat penting.

Pada saat terjadi perjanjian jual beli, pihak penjual memberikan jaminan yang ber-upa garansi selama beberapa waktu tertentu atas komputer rakitan yang dibeli konsumen. Menurut pihak toko, masa garansi merupakan suatu masa dimana konsumen dapat melihat, mengamati, menentukan dan meneliti keadaan komputer yang dibelinya, dan masa garansi tersebut sudah merupakan suatu toleransi yang demokratis bagi konsumen, sehingga apabila komputer yang dibeli tidak sesuai dengan yang diperjanjikan, konsumen dapat mengajukan klaim pada pihak toko

Layanan purna jual merupakan kepentingan konsumen yang sangat vital dewasa ini. Utamanya berkenaan dengan teknologi perangkat komputer, sering membuat produsen harus mengubah tipe-tipe produknya mengikuti selera dan kebutuhan konsumen yang terus berganti dalam waktu yang singkat. Akibatnya jika ada kerusakan dari suatu tipe produk sering konsumen tertentu menghadapi kendala memperbaiki barangnya karena ketiadaan suku cadang.

Menyangkut layanan purna jual adalah soal garansi. Dalam jangka waktu tertentu yang diberikan produsen atau penyalur produk (penjual) kepada konsumennya demikian pula dengan tanggung jawab produsen atau penyalur produk (penjual) atau kreditur dalam memenuhi hak konsumen, terutama hak untuk memperoleh barang atau jasa yang sesuai dengan nilai tukar yang diberikan. Konsumen tidak boleh ditipu memperoleh barang kualitas tertentu padahal kenyataannya tidak demikian. Tampak masalah layanan purna jual adalah masalah perlindungan konsumen yang tidak dapat dipisahkan dengan tahap-tahap transaksi konsumen yang lainnya, yang berlaku bukan lagi prin- 
sip caveat emptor melainkan caveat venditor (produsen atau penyalur produk atau krediturlah yang bertanggung jawab), yang lazim disebut tanggung jawab produk. Tanggung jawab dari produsen dan pihak-pihak yang menyalurkan produknya secara tanggung renteng seluruhnya bersifat tanggung jawab mutlak (strick liability) atau tanggung jawab tanpa kesalahan (liability without fault). ${ }^{22}$

Seharusnya tanggung jawab produk jangan dibatasi hanya pertanggung jawaban atas produk yang cacat. Tanggung jawab produk adalah bagian dari transaksi konsumen yaitu tahap ketiga. Membatasi tanggung jawab produk hanya pada pergantian atas produk yang cacat berarti tidak memberikan banyak per-lindungan kepada konsumen.

Sudah menjadi kewajiban produsen untuk menjamin barang yang dijualnya itu bebas dari cacat tersembunyi. J aminan ini merupakan perikatan yang otomatis dibebankan kepada produsen atau penyalur produk (penjual). Jaminan undang-undang inipun dalam praktek dicoba untuk diminimalisasi dengan pernyataan sepihak yang dibuat oleh penjual (pihak toko) sehingga dapat bebas dari tanggung jawab dari cacat tersembunyi tersebut.

Pasal 19 UU No. 8 Tahun 1999 secara jelas mengatur, pelaku usaha wajib mengganti kerugian atas kerusakan, pencemaran dan atau kerugian yang diderita konsumen akibat mengkonsumsi barang dan atau jasa. Ganti kerugian itu bersifat serta merta dan diberi jangka waktu tujuh hari setelah tanggal transaksi. Namun, ketentuan ini agak berbeda dengan ketentuan tentang masa garansi dalam Pasal 27 undangundang perlindungan konsumen. Ketentuan dalam pasal yang disebutkan terakhir ini memberi tenggang waktu pelayanan kepada konsumen sampai pada masa akhir garansi

Layanan purna jual sebenarnya meliputi permasalahan yang lebih luas dan terutama mencakup masalah kepastian atas beberapa hal. Pertama, ganti rugi jika barang yang dibe-

22 Dyah Ika Rinawati, "Strategi Perbaikan Penggantian Berdasarkan Umur Produk Untuk Garansi Satu Dimensi" J urnal TEKNIK Universitas Diponogoro, Semarang, Vol. 32 No. 1 Tahun 2011, hlm. 18, rikan tidak sesuai dengan perjanjian semula; kedua, barang yang digunakan, jika mengalami kerusakan tertentu, dapat diperbaiki secara cuma-cuma selama jangka waktu garansi; dan ketiga, suku cadang selalu tersedia dalam jumlah cukup dan tersebar luas dalam jangka waktu yang relatif lama setelah transaksi konsumen dilakukan.

Layanan purna jual diakomodasikan pula dalam UU No.8 Tahun 1999, walaupun hanya dalam beberapa rumusan yang umum. Pasal 25 merumuskan, pelaku usaha yang memproduksi barang yang pemanfaatannya berkelanjutan dalam batas waktu yang sekurang-kurangnya satu tahun, wajib menyediakan suku cadang dan/ atau fasilitas purna jual dan wajib memenuhi jaminan atau garansi sesuai dengan yang diperjanjikan. Pelaku usaha sebagaimana yang dimaksud pada ayat (1) Pasal 25 bertanggung jawab atas ganti rugi dan/atau gugatan konsumen apabila pelaku usaha tersebut tidak menyediakan atau lalai menyediakan suku cadang dan/atau fasilitas perbaikan tidak memenuhi atau gagal memenuhi jaminan atau garansi yang diperjanjikan.

Jelaslah penyelesaian kasus purna jual seperti dinyatakan dalam Pasal 25 undangundang perlindungan konsumen itu masih memerlukan upaya penuntutan ganti rugi dan atau gugatan konsumen. Pasal 27 huruf (e) undangundang perlindungan konsumen bahkan memberi batas waktu kadaluwarsa untuk melakukan penuntutan atau gugatan itu selama empat tahun sejak barang dibeli atau setelah lewat masa garansi.

Persoalannya adalah bahwa pelaku usaha sering secara sepihak mencantumkan masalah garansi secara tidak proporsional. Misalnya untuk garansi perbaikan sebuah komputer rakitan ditetapkan lamanya satu bulan sejak diserahkan kembali. Waktu yang demikian pendek sangat mungkin tidak mencukupi bagi konsumen untuk meneliti kembali hasil perbaikan itu secara keseluruhan. Untuk itu masa garansi ini pun perlu ditetapkan batas minimalnya oleh pembentuk undang-undang, bergantung pada 
jenis barang atau jasa yang diberikan oleh pelaku usaha itu. ${ }^{23}$

Khusus untuk produk elektronika pengaturan tentang layanan purna jual dicantumkan dalam Keputusan Menteri Perindustrian dan Perdagangan No. 608/MPP/Kep/10/1999 tentang petunjuk penggunaan (manual) dan kartu jaminan / garansi dalam bahasa Indonesia bagi produk elektronika. Dalam keputusan itu disebutkan bahwa manual atau kartu jaminan atau garansi produk elektronika tertentu perlu dilakukan pendaftaran. Dalam peraturan yang disebutkan di atas hanya sebelas jenis produk elektronika yang diwajibkan pendaftaran, yaitu radio cassette/mini compo, alat perekam atau reproduksi gambar, pesawat televisi, printer, monitor komputer, lemari es, mesin pengatur suhu ruangan atau ac, mesin cuci, kompor gas, pompa air listrik untuk rumah tangga dan micro oven Dalam keputusan itu tidak jelas alasannya mengapa produk elektronika yang diwajibkan pendaftarannya hanya dibatasi sebelas jenis produk tersebut. Kesebelas jenis produk ini wajib dilengkapi manual bahasa Indonesia, termasuk produk yang diimpor dari luar negeri. Manual tersebut sekurang-kurangnya wajib memuat informasi tentang petunjuk operasi penggunaan, petunjuk perbaikan atau pemeliharaan dan spesifikasi produk.

Sebelas jenis produk yang beredar di Indonesia juga wajib dilengkapi kartu jaminan atau garansi dalam bahasa Indonesia. Kartu jaminan atau garansi itu berlaku sekurang-kurangnya satu tahun yang antara lain wajib memuat informasi mengenai ongkos perbaikan gratis selama masa garansi dan jaminan ketersedian suku cadang. Jelas disini suatu komputer rakitan tidak mendapat perlindungan dari Keputusan Menteri Perindustrian dan Perdagangan No. 608/MPP/ Kep/10/1999 tentang petunjuk penggunaan (manual) dan kartu jaminan/garansi dalam bahasa Indonesia bagi produk elektronika. Seharusnya suatu komputer rakitan juga mendapat layanan purna jual yang sama de-

\footnotetext{
23 Azizah Kamil, "Pengaruh Pelayanan Purna J ual terhadap Kepuasan konsumen Dalam membeli Sepeda Motor Mio", J urnal ILMIAH STIE APRIN, Palembang, Vol. 3 No. 3, Tahun 2011, hlm. 54,
}

ngan sebelas produk elektonik sebab melihat dari semakin penting dan umum dipakai oleh masyarakat. Keputusan Menteri Perdagangan diatas memberikan dasar hukum tentang garansi disamping ketentuan jaminan garansi yang diberikan oleh UU No.8 Tahun 1999 sehingga diharapkan ada aturan yang lebih rinci mengenai jaminan garansi dan layanan purna jual (sale after service)

\section{Faktor Penghambat Praktek Transaksi Jual Beli Komputer Rakitan}

Komputer rakitan menjadi pilihan utama oleh konsumen akibat harganya yang murah, bila dibandingkan dengan harga sebuah komputer branded (merk terkenal) selisihnya terpaut jauh, disamping itu pembeli dapat merakit komputer seperti yang diinginkan tanpa terpatok pada suatu jumlah harga sebab pemilihan komponennya dapat disesuaikan dengan kebutuhan dan selera pembeli, konsekuensinya komputer rakitan yang dibelinya kurang berkualitas karena dirakit dari berbagai jenis komponen dengan merk dan produsen berbeda. Dalam praktik transaksi jual beli komputer rakitan, terdapat beberapa hambatan-hambatan, baik itu yang datangnya dari penjual (pihak toko) ataupun pembeli (konsumen), hal ini diakibatkan masih belum dikenal luasnya perihal komputer rakitan yang mempunyai perbedaan secara prinsip dalam transaksi perdagangannya dengan komputer branded (merk terkenal) yang menimbulkan hambatan yang datangnya dari penjual maupun pembeli untuk selanjutnya mencari cara mengatasinya hambatan tersebut. Penulis akan menjabarkannya seperti dibawah ini.

Penjual komputer rakitan adalah pihak yang paling tahu dan berkepentingan sehubungan dengan produk yang akan dipasarkannya, namun pada kenyataannya banyak penjual yang hanya menjadikan konsumen sebagai obyek dari suatu sistem pemasaran. Banyak fakta di lapangan, dimana pihak penjual menggunakan berbagai macam cara guna menjual komputer mereka sebanyak-banyaknya dari sudut pandang penjual sangat menguntungkan namun secara umum praktek yang dilakukan menjadi faktor 
penghambat dari transaksi jual beli komputer rakitan.

Penggunaan media iklan oleh penjual (pemasar produk) untuk menarik pembeli sebanyak-banyaknya tanpa memberikan informasi produk yang dijualnya secara rinci dan jelas. Terkadang mencantumkan harga yang murah dalam iklan yang dibuat, namun setelah pembeli datang, maka harga dinaikkan secara sepihak oleh penjual baik dengan alasan nilai tukar dollar berubah ataupun dengan alasan harga komponennya sudah naik sehingga penjual dapat mengambil keuntungan dari selisih kurs patokan dollar Amerika Serikat.

Tidak adanya jaminan dari penjual, sekarang tetap eksis dalam perdagangan komputer rakitan diwaktu mendatang mengakibatkan sulitnya dalam pelayanan purna jual (jaminan garansi). Sebab pembeli hanya mempunyai hubungan dengan penjual yang bersangkutan, yang menjadi kesulitan banyaknya dealer utama dari komponen-komponen dalam sebuah komputer rakitan sehingga apabila ada kerusakan atas komputer secara umum atau salah satu komponen, pembeli tidak dapat meminta tanggung jawab dari dealer utama tapi hanya sebatas dengan pihak toko dimana komputer itu dirakit.

Perjanjian jual beli komputer rakitan yang dilakukan secara tidak tertulis sehingga menyulitkan dalam pembuktian berkaitan, penjual melakukan wanprestasi terhadap perjanjian yang telah dibuat seperti memasang komponen yang tidak sesuai dengan yang diperjanjikan sebelumnya malah memasang komponen bekas dalam komputer rakitan tanpa sepengetahuan dari pembeli (konsumen) hanya untuk memperoleh keuntungan dari penjualan komputer rakitan tersebut. Hal ini dimungkinkan karena karakteristik dari komputer rakitan itu sendiri yang dirakit oleh penjual sendiri sehingga tidak menutup kemungkinan penjual memasangkan komponen yang tidak sesuai dengan yang diperjanjikan.

Dari hasil pengamatan dan penelitian dalam perjanjian jual beli komputer rakitan pihak penjual memberikan jaminan garansi kurang dari waktu yang ditentukan pabrik (pihak pro- dusen) komponen yang mana dalam hal ini jangka waktu 6 (enam bulan), tanpa mengikuti masa garansi yang dikeluarkan oleh produsen komponen sehingga jelas merugikan pembeli (konsumen), garansi yang diberikan menyangkut layanan service gratis atas komputer rakitan yang dibeli termasuk pada juga komponenkomponen yang terpasang pada komputer tersebut.

Lambannya penanganan perbaikan sebuah komputer rakitan yang rusak dalam masa garansi dimana pembeli (konsumen) terpaksa meninggalkan komputernya yang rusak di tempat penjual (toko) berhari-hari, jelas komputer pembeli tidak dapat digunakan pada waktu komputer dalam perbaikan yang akan membawa kerugian pada pihak konsumen dimana pihak penjual (toko) tidak mau memberikan komputer pinjaman kepadanya.

Faktor penghambat yang datangnya dari konsumen komputer rakitan adalah kurang memahami tentang komputer rakitan dan ter-lalu percaya kepada penjual. Biasanya dalam memilih komponen komputer rakitan, pembeli (konsumen) mempercayakan kepada penjual. Sehingga penjual sering memanfaatkan kondisi tersebut untuk menyalahgunakan kepercayaan pembeli yang tidak paham terhadap komputer. Masih banyaknya konsumen yang menjadikan harga sebagai pertimbangan utama tanpa memperdulikan masalah kualitas dan pelayanan purna jualnya dari penjual komputer rakitan, pada akhirnya konsumen kecewa terhadap komputer yang dibelinya karena rendahnya kualitas dan tidak adanya layanan purna jual dari penjual.

Adanya konsumen yang tidak beritikad baik dalam menggunakan komputer yang dibelinya, menimbulkan kerusakan terhadap komputernya dengan asumsi bahwa barang yang dibelinya masih dalam masa garansi sehingga digunakan diatas kemampuan dan kapasitas dari komputer itu sendiri sehingga sulit untuk dibuktikan apakah kerusakan itu timbul akibat salah pemakaian oleh konsumen atau memang karena cacat produksi dari produsen sendiri, dengan demikian banyak menimbulkan persoalan sebab 
kerusakan komponen komputer sangat sulit diketahui dari bentuk fisiknya.

Kurang paham dan terampil dalam mengoperasikan komputer mengakibatkan rusaknya software (program) dan hardware (komponen) dari komputer rakitan yang dibeli sehingga cukup merepotkan pihak penjual menjelaskan kepada pembeli tentang komputer rakitan yang dibelinya dari penjual. Rusak atau hilangnya segel/label tanda garansi toko karena kesegajaan, dibuka tanpa sepengetahuan dari toko di mana kita membeli komputer rakitan tersebut sehingga apabila terjadi kerusakan keluhan (klaim) tidak bisa dilayani sebab, segel tersebut merupakan penanda jaminan garansi yang diberikan.

\section{Penyelesaian Hambatan dalam Praktek Tran- saksi J ual Beli Komputer Rakitan}

Untuk mengatasi hambatan-hambatan yang timbul dalam praktek transaksi jual beli komputer rakitan dapat dilakukan usaha pencegahan baik oleh pihak pembeli dan penjual sehingga masing-masing pihak merasa puas berkenaan transaksi yang dilakukannya. Pihak Penjual dalam hal ini Bintan Risky Computer (BRC) Surabaya melakukan berbagai upaya untuk mengatasi hambatan-hambatan yang timbul antara lain: pertama, dalam melakukan promosi (iklan) komputer rakitan yang akan dijual dalam brosur iklannya BRC Surabaya mencantumkan klausula eksenorasi artinya di akhir iklan disebutkan bahwa harga dan spesifikasi komputer rakitan akan berubah sewaktu-waktu, hal ini dikarenakan perubahan harga dari komputer yang masih menggunakan patokan dollar dan ketersediaan komponen dari dealer yang tidak tetap; kedua, dalam tahap perjanjian jual beli komputer rakitan pihak BRC Surabaya akan menerangkan hak dan kewajiban para pihak kepada pembeli secara lisan sehubungan dengan komputer rakitan yang dibelinya baik spesifikasi komponen-komponen yang dirakit dalam komputer yang ditulis dalam kuitansi pembelian, masalah purna jual menyangkut juga jangka waktu jaminan garansi dan sistem pembayarannya; dan ketiga, jaminan garansi diberikan selama waktu tertentu yang diperjanjikan (di BRC
Surabaya jaminan garansi diberikan selama enam bulan) untuk komputer rakitan yang dibeli konsumen dengan cara menempelkan label garansi toko terhadap semua komponen dan menuliskan tanggal akhir masa garansinya guna memastikan komponen tersebut dari penjual sendiri (BRC Surabaya) dan untuk membuktikan tidak pernah diservis oleh pihak lain yang akan mengakibatkan jaminan garansi batal.

Konsekuensi memilih komputer rakitan yang jaminan kualitas kurang baik maka pihak konsumen harus menerapkan prinsip teliti sebelum membeli sebab seperti diketahui adanya hambatan-hambatan yang timbul dalam praktik transaksi jual beli komputer rakitan. Langkahlangkah yang dapat diambil antara lain: pertama, memilih penjual (toko komputer) yang mempunyai reputasi baik dalam kaitannya pelayanan kepada pembelian (konsumen) sehingga pembeli atau konsumen tidak dirugikan oleh pihak penjual (produsen), biasanya penjual memberikan pelayanan konsultasi berkaitan dengan komputer yang akan dibeli; kedua, toko komputer yang mempunyai nama relatif mempunyai pelayanan yang profesional, menghindari membeli komputer rakitan dari perorangan karena akan kesulitan dalam kaitannya dengan layanan purna jual (jaminan garansi) dari komputer yang dibeli; ketiga, dalam membeli komputer rakitan harus dilihat kebutuhan yang mana bisa dikonsultasikan kepada penjual dengan membandingkan beberapa penjual untuk mendapat pelayanan dan harga terbaik, sehingga dapat dicegah pengeluaran yang tidak perlu; keempat, meminta penjelasan yang cukup serta petunjuk penggunaan atas komputer rakitan yang dibeli oleh konsumen, beserta hak dan kewajiban yang didapat dari penjual berkaitan dengan komputer rakitan yang dibeli; dan kelima, dalam perjanjian jual belinya diusahakan secara tertulis artinya komponen dalam komputer rakitan tersebut disebutkan secara rinci dan detail serta berkaitan dengan jaminan garansi apakah diberikan perkomponen dengan jangka waktu garansi berbeda atau secara keseluruhan (well Packet) harus dijelaskan dalam perjanjian tersebut. 
UU No. 8 Tahun 1999 mengatur mengenai penyelesaian sengketa, dimana konsumen dapat menggugat pelaku usaha melalui lembaga yang bertugas menyelesaikan sengketa yang terjadi antara konsumen dan pelaku usaha yaitu BPSK atau melalui peradilan yang berada di lingkungan peradilan umum. Penyelesaian melalui peradilan yang berada di lingkungan peradilan umum dalam kenyataan tidak menguntungkan para pihak baik konsumen dan pelaku usaha sebab lama dan panjangnya proses acaranya sehingga penyelesaian melalui BPSK yang mempunyai kewenangan menyelesaikan sengketa dan menjatuhkan sanksi administratif sesuai Pasal 60 terhadap pelaku usaha yang melanggar sangat tepat walaupun sampai saat ini kinerjanya belum optimal, sehingga undang-undang ini belum sepenuhnya dapat ditegakkan.

BPSK menjadi barisan terdepan dalam melindungi hak-hak konsumen bersama dengan lembaga swadaya masyarakat yang bergerak dalam kegiatan perlindungan konsumen dan lembaga yang mewakili pelaku usaha (penjual komputer rakitan) sangat penting. Dari hasil penelitian di lapangan ada dua lembaga swadaya masyarakat yang dapat dijadikan media guna mengatasi hambatan serta penyelesaian sengketa antara konsumen dan pelaku usaha (penjual komputer) yaitu Yayasan Lembaga Konsumen Surabaya (YLKS) dan Assosiasi Pedagang Komputer (APKOM)

Assosiasi Pedagang Komputer (APKOM) sebagai suatu bentuk perhimpunan pedagang komputer di mana lebih dari 70 persen anggotanya bergerak dibidang usaha komputer rakitan. APKOM sendiri merupakan wadah bagi para pedagang komputer yang bersifat sukarela artinya tidak berarti semua pedagang menjadi anggotanya dan tujuan dari dibentuknya antara lain adalah: perlindungan para pedagang komputer dari para pedagang lain yang tidak beritikad baik; pemberdayaan para anggota dengan mengadakan berbagai seminar tentang strategi pemasaran, peningkatan kemampuan manajerial para anggotanya; kerjasama dengan instansi pemerintah atau pihak swasta dalam kaitannya dengan pengadaan komputer dimana
APKOM memberikan sertifikasi kepada anggotanya yang melakukan kerja sama (rekanan) dengan instansi pemerintah atau pihak swasta tersebut; dan sebagai organisator dan pelaksana dari suatu pameran komputer yang bertujuan sebagai usaha promosi dan peningkatan penjualan dari anggotanya. ${ }^{24}$

Tujuan dari dibentuknya APKOM diatas masih sebatas untuk kepentingan para pedagang komputer, namun APKOM nantinya dapat dijadikan rujukan guna mendapatkan informasi tentang pedagang komputer yang mempunyai reputasi baik dalam hal pelayanan kepada konsumen sehingga menjadi pertimbangan bila akan membeli komputer rakitan karena adanya jaminan dari APKOM. Ada beberapa langkah yang dilakukan oleh konsumen untuk pengajuan permohonan penyelesaian sengketa konsumen (PSK) di BPSK Surabaya, isi permohonan PSK di syaratkan memuat benar dan lengkap identitas konsumen, ahli waris atau kuasanya disertai bukti; nama dan alamat pelaku usaha; barang dan jasa yang diadukan; bukti perolehan, keterangan tempat, waktu dan tanggal perolehan barang dan jasa yang diadukan; saksi yang mengetahui perolehan barang atau jasa, foto-foto barang dan jasa bila ada. ${ }^{25}$ Selanjutnya permohonan PSK dicatat sekretariat BPSK sesuai dengan format yang telah disediakan. Permohonan PSK dibubuhi tanggal dan nomor registrasi, permohon diberi bukti tanda terima. Pemanggilan terhadap pelaku usaha untuk hadir di persidangan BPSK dilakukan secara tertulis dengan salinan permohonan penyelesaian konsumen dalam waktu tiga hari kerja sejak permohonan diterima lengkap. Dalam pemeriksaan persidangan ada tiga tata cara yaitu persidangan dengan cara konsiliasi, persidangan dengan cara mediasi dan persidangan dengan cara arbitrase.

Namun dalam kenyataannya, pembeli (konsumen) komputer rakitan tidak ada yang mengadukan pelanggaran yang dilakukan oleh penjual (pelaku usaha) hal ini didapat dari hasil data di BPSK Surabaya. Para pihak lebih senang me-nyelesaikan masalahnya secara kekeluarga-

24 Wawacara Pengurus APKOM J atim, 21 Desember 2005,

25 Wawancara dengan pengurus BPSK, $20 \mathrm{~J}$ anuari 2006 , 
an dengan pihak penjual sebab beranggapan tidak ada gunanya mengadu ke BPSK sebab nilai kerugian yang diderita oleh konsumen tidak sebanding dengan biaya yang akan dikeluarkan apabila melaporkan adanya pelanggaran yang dilakukan penjual.

Penyelesaian sengketa secara kekeluargaan akibat dari hambatan-hambatan dalam transaksi jual beli komputer rakitan antara pembeli (konsumen) dengan penjual (pihak toko) dirasa paling tepat dan efektif apalagi komputer yang rusak masih dalam status masa garansi yang merupakan bagian dari tahap pasca transaksi (sale after service), dimana UU No.8 Tahun 1999 sudah mengaturnya di samping ketentuan dalam Keputusan Menteri Perindustrian dan Perdagangan No. 608/ MPP/ Kep/ 10/ 1999 seperti dijelaskan diatas.

Berkaitan dengan belum adanya kesadaran masyarakat utamanya konsumen untuk menggugat/ mengajukan Permohonan PSK melalui BPSK atau-pun lembaga peradilan bagi pelaku usaha yang melakukan pelanggaran khususnya dalam transaksi jual beli komputer rakitan, selain banyaknya hambatan sehingga penulis sependapat dengan apa yang dikemukan Sudaryatmo bahwa ada 3 faktor yang menentukan cepat tidaknya keluhan pembeli (konsumen) ditanggapi oleh pelaku usaha, yaitu: pertama, siapa pengadu, apabila pengadu seorang figur akan mendapatkan tanggapan berbeda dibandingkan pengadu seorang konsumen biasa; kedua, kepada siapa mengadu, apabila pembeli mempunyai akses keatas, mengadu pada pemimpin dari suatu toko yang menjual komputer rakitan maka akan mendapat tanggapan yang berbeda dibandingkan mengadu ke bawahannya; dan ketiga, dalam situasi apa mengadu, apabila konsumen mendapat kesempatan untuk mengutarakan keluhan dalam suatu acara yang diliput media massa, atau menulis keluhannya melalui koran maka pihak toko tidak mau berspekulasi untuk tidak memberikan tanggapan yang manis-manis kepada konsumen. ${ }^{26}$

26 Abdul Hakim Barkatullah, "Urgensi Perlindungan Hakhak Konsumen Dalam Transaksi Di E-Commerce", J urnal Hukum, Fakultas Hukum Universitas Islam Indonesia, Vol. 14 No. 3 2007, hlm 252,; bandingkan dengan

\section{Penutup \\ Simpulan}

Perlindungan hukum dalam transaksi jual beli komputer rakitan sangat penting karena semakin umumnya komputer dipakai dalam masyarakat, berkaitan dengan pelaksanaan perjanjian jual beli komputer rakitan antara pembeli (konsumen) dan penjual yang dijadikan dasar adalah KUHPerdata buku ketiga khususnya mengenai jual beli dan disamping berpedoman kepada UU No. 8 Tahun 1999 dengan tidak menutup kemungkinan dibuat sendiri oleh para pihak terutama oleh pihak penjual. UU No. 8 Tahun 1999 secara umum sudah memberikan perlindungan hukum bagi para pihak utamanya konsumen dimana secara garis besar dapat di bagi dalam tiga tahap yaitu tahap pra transaksi atau penawaran komputer rakitan melalui iklan, tahap transaksi atau perjanjian jual beli komputer rakitan dan yang terakhir tahap pasca transaksi (sale after service) yang menyangkut juga tentang jaminan garansi.

Hambatan-hambatan dalam transaksi jual beli komputer rakitan yang timbul dari penjual seperti rendahnya kualitas mutu komputer tersebut, harga maupun spesifikasi barang yang ditawarkan dalam iklan tidak sama dengan persediaan barang, perjanjian jual beli komputer rakitan biasanya tidak tertulis, penjual memasang komponen berbeda dengan yang diperjanjikan, harga yang mengikuti fluktuasi nilai tukar dollar serta tidak adanya jaminan dari penjual, sekarang tetap eksis sampai masa garansi komputer yang dibeli konsumen berakhir, sedangkan hambatan yang datangnya dari pihak pembeli (konsumen) kurangnya pengetahuan terhadap komputer yang akan dibeli sehingga menyerahkan pemilihan komponen sepenuhnya kepada penjual, pihak pembeli yang tidak beritikad baik dalam menggunakan komputernya di luar batas kemampuannya dengan asumsi masih dalam masa garansi. Untuk mengatasi hambatan-hambatan dalam praktek transaksi jual beli komputer rakitan maka para pihak dalam hal ini penjual dan pembeli selalu memperhatikan hak dan kewajibannya secara bertanggung ja-

Sudaryatmo, Hukum dan Advokasi Konsumen, Cet II Citra Aditya Bakti, Bandung, 1999 hlm. 102, 
wab dalam perjanjian yang dibuatnya, sebagai penjual (toko komputer) yang paling tahu sehubungan komputer rakitan yang dijual harus memperhatikan ketentuan dalam UU No. 8 Tahun 1999. Pada umumnya bentuk penyelesaikan sengketa dalam transaksi jual beli komputer rakitan dilakukan secara kekeluargaan antara pembeli (konsumen) dengan penjual (pihak toko) hal ini paling tepat dan efektif, walaupun UU No. 8 Tahun 1999 juga memberikan saluran untuk mengadukan kasusnya melalui BPSK yang memang mempunyai kewenangan menyelesaikan sengketa dan menjatuhkan sanksi administratif terhadap pelaku usaha yang melanggar.

\section{Saran}

Transaksi jual beli komputer rakitan seharusnya dituangkan dalam bentuk perjanjian tertulis dimana dijelaskan hak dan kewajiban para pihak, informasi tentang petunjuk operasi penggunaan, petunjuk perbaikan atau pemeliharaan dan spesifikasi produk (komponen-komponen yang dirakit disebutkan secara jelas dan rinci mengenai merk, kapasitas), dan jaminan garansi harus di-cantumkan dalam perjanjian jual beli komputer rakitan, sehingga para pihak tahu akan hak dan kewajibannya. Untuk mengefektifkan UU No. 8 Tahun 1999 maka pemerintah harus mengoptimalkan fungsi BPSK yang mempunyai kewenangan menyelesaikan sengketa dan menjatuhkan sanksi administratif kepada pelaku usaha yang melanggar, di luar penyelesaian melalui jalur pengadilan. Bisa dilakukan pula dengan banyak memberikan sosialisasi, penyuluhan dan pelatihan tentang perlindungan konsumen serta informasi tentang tugas dan wewenang dari BPSK. Perlu di tingkatkan peran dari Yayasan Lembaga Konsumen Surabaya (YLKS) dan Assosiasi Pedagang Komputer (APKOM) sehingga kedua lembaga swadaya masyarakat itu dapat berperan dalam mengatasi hambatan-hambatan dalam transaksi jual beli komputer serta turut mensosialisasikan UU No. 8 Tahun 1999 sehingga dikenal secara luas oleh masyarakat.

\section{Daftar Pustaka}

Barkatullah, Abdul Hakim. "Bentuk Perlindungan Hukum Bagi Konsumen dalam Penyelesaian Sengketa Transaksi Elektronik Internasional menurut UU No. 11 Tahun 2008". Jurnal Hukum Bisnis. Vol. 29 No. 1 Tahun 2010;

"Urgensi Perlindungan Hak-hak Konsumen Dalam Transaksi Di E-Commerce". Jurnal Hukum. Vol.2 No. 4 April 2007. Yogya-karta: Fakultas Hukum Universitas Islam Indonesia;

Hariyanto, Erie. "Problematika dan Perlindungan Hukum e-Commerce di Indonesia". J urnal Al-Ihkam. Vol. 4 No.2 Desember 2009. Pamekasan: Jurusan Syariah STAIN Pamekasan;

Irna Nurhayati. "Efektifitas Pegawasan Badan Pengawasan Obat dan Makanan Terhadap Peredaran Produk Pangan Olahan Impor dalam mewujudkan Perlindungan Konsumen". Jurnal Mimbar Hukum, Vol. 21 No. 2 J uni 2009. Yogya-karta: FH UGM;

Kamil, Azizah. "Pengaruh Pelayanan Purna J ual terhadap Kepuasan Konsumen Dalam Membeli Sepeda Motor Mio, J urnal ILMIAH STIE APRIN Palembang. Vol.3 No.3 2011. Palembang: Sekolah Tinggi IImu Ekonomi Akademi Perindustrian;

Kurniawan dan Abdul Wahab. "Tinjauan Yuridis Terhadap Prosedur Penyelesaian Sengketa Konsumen Melalui BPSK di Indonesia". J urnal Hukum J atiswara. Vol 23 No.2 Juli 2008. Nusa Tengara Barat: Fakultas Hukum Universitas Mataram;

"Permasalahan dan Kendala Penyelesaian Sengketa Konsumen melalui Badan Penyelesaian Sengketa Konsumen(BPSK)". Jurnal Dinamika Hukum. Vol. 12 No. 1 Tahun 2012. Purwokerto: Fakultas Hukum Universitas J enderal Soedirman;

Margono, Suyud. 2001. Perlembagaan Alternatif Dispute Resolution (ADR) dalam Prospek dan Pelaksanaannya di ndonesia, Bandung : PT Citra Aditya Bakti;

Mulyono, Fransisca. "Informasi Produk Dalam Iklan dan Perlindungan Konsumen di Indonesia". Jurnal Bina Ekonomi. Vol. 4 No. 2 Agustus Tahun 2010. Bandung: Universitas Parahyangan;

Panggabean, R.M. "Keabsahan Perjanjian dengan Klausul Baku". J urnal Hukum. Vol. 17 No. 4 Oktober 2012. Yogyakarta: Fakultas Hukum UII; 
Pratiwi, Wiwik. "Keseimbangan Hak dan Kewajiban Antara Produsen dan Konsumen". Jurnal Ilmiah Inkoma. Vol. 18 No. 1 Februari 2007. Semarang: FH UNISSULA ;

Rajagukguk, Erman. "Budaya Hukum dan Penyelesaian Sengketa di Luar Pengadilan". Jurnal Magister Hukum. Vol.2 No. 4 Tahun 2000. Yogyakarta: PPs-UII;

Rinawati, Dyah Ika. "Strategi Perbaikan Penggantian Berdasarkan Umur Produk Untuk Garansi Satu Dimensi". J urnal TEKNIK. Vol.32 No. 1 Tahun 2011. Semarang: Universitas Diponogoro;

Shahrullah. "Modern Arbitration Legislation: A Comparosion Between Australia and Indonesia Law" J urnal Mimbar Hukum Vol 24 No. 2. J uni 2012. Yogyakarta: Fakultas Hukum UGM;
Shofie, Yusuf. 2003. Penyelesaian Sengketan Konsumen Menurut UUPK. Jakarta : Citra Aditya Bakti;

Sudaryatmo. 1999. Hukum dan Advokasi Konsumen. Bandung: Citra Aditya Bakti;

Sugarda, Paripurna P. "Kontrak Standart: Prinsip kehati-hatian Bank dan Perlindungan Debitur". Jurnal Mimbar Hukum. Vol. 20 No. 2 J uni 2008. Yogya-karta: Fakultas Hukum UGM;

Sulistiyono, Adi. "Musyawarah Untuk Penyelesaian Sengketa Win-Win solution dalam Perspektif Hukum". J urnal Hukum Bisnis. Vol. 25 No. 1. Tahun 2006. Jakarta: Yayasan Pengembangan Hukum Bisnis. 